\title{
A banalidade do mal e as possibilidades da educação moral: contribuições arendtianas
}

\author{
Marcelo Andrade \\ Pontifícia Universidade Católica do Rio de Janeiro, Departamento de Educação
}

\section{Introdução}

Talvez se tenha tornado comum afirmar que vivemos em tempos dificeis ou, para usar uma expressão arendtiana, em "tempos sombrios". Crise econômica e do sistema financeiro, crise de confiança nas instituições, crise de valores, crise energética, crise de sustentabilidade, mudanças climáticas e catástrofes ambientais, crises dos paradigmas, mudanças epistemológicas, guerras e terrorismos, intolerâncias religiosas e, não menos grave, crise do sistema educativo. Tempos tão difíceis ou sombrios que talvez já tenhamos escutado a expressão crise de época, para sinalizar que não vivemos simplesmente mais uma época de crises.

Seria legítimo, então, perguntar-nos sobre que papel poderia desempenhar, nesses tempos sombrios, o pensamento educacional ou como ele nos poderia ajudar a compreender e a superar os desafios que se impõem. Arendt (1987, p. 7), ao analisar os horrores do século passado, afirmava que os "tempos sombrios não são novos" e "não constituem uma raridade na história". No entanto,

\footnotetext{
[...] mesmo no tempo mais sombrio temos o direito de esperar alguma iluminação, e que tal iluminação pode bem provir, menos das teorias e conceitos, e mais da luz incerta, bruxuleante e frequentemente fraca que alguns homens e mulheres, nas suas vidas e obras, farão brilhar em quase todas as circunstâncias e irradiarão pelo tempo que lhes foi dado na terra (idem, ibidem).
}

É com esse ponto de vista que gostaria de sugerir a retomada de um episódio marcante na vida dessa pensadora perspicaz: o julgamento do oficial nazista Adolf Eichmann. Diante de um estranho réu, Hannah Arendt confrontou-se com as sombras e as dificuldades de seu tempo. Talvez ela também tenha pistas - luzes incertas - para pensar nossas sombras; talvez possamos repensar com ela a tarefa educativa, principalmente no que tange ao ensino e à difusão de valores morais. É nessa perspectiva que 
tratarei de analisar a obra arendtiana, com especial atenção aos livros Eichmann em Jerusalém e $A$ vida do espírito.

\section{Um conceito e muitas polêmicas}

Eichmann em Jerusalém (Arendt, 1999) é resultado de um relato sobre o processo e o julgamento de Adolf Eichmann, realizado em Jerusalém em 1961. Talvez esta tenha sido a obra mais polêmica de Hannah Arendt. Depois do célebre As origens do totalitarismo (Arendt, 1989), Eichmann em Jerusalém significou sua perda de prestígio na intelectualidade judaica em Israel, na Europa e nos Estados Unidos. Foi considerado o livro mais polêmico em língua inglesa da década de 1960, levando em conta o número de artigos, cartas públicas, debates, réplicas, tréplicas, defensores e detratores que a obra envolveu (Assy, 2001a, p. 156).

Hannah Arendt tentou manter-se afastada dessa repercussão. Ela respondeu apenas às críticas de amigos próximos e de intelectuais que respeitava, como foi o caso de Gershom Scholem, respeitado historiador judeu que ela tanto apreciava. Scholem publicou uma carta aberta, na qual afirma que Arendt não possuía “amor pelo povo judeu" (Watson, 2001, p. 80). Ela respondeu de maneira categórica, afirmando que não havia negado sua identidade judaica, mas também não a apresentou como uma condição especial:

\footnotetext{
Sempre entendi minha condição de judia como um fato inegável da minha vida e jamais pretendi mudar isso ou rejeitar tal condição. Nesse sentido, eu não "amo" os judeus, nem "acredito" neles: simplesmente pertenço ao judaísmo, naturalmente, para além de qualquer controvérsia ou contestação. (Arendt apud Young-Bruehl, 1997, p. 299)
}

Lafer (2003) e Watson (idem) concordam que Hannah Arendt desagradou a muitos: o povo judeu, acusado de falta de resistência e passividade; a elite judaica, acusada de ingenuidade e cumplicidade; o povo alemão, acusado de omissão e conivência; os políticos alemães do pós-guerra, acusados de não terem punido funcionários da burocracia nazista que ainda trabalhavam em órgãos do governo; a juventude alemã, acusada de teatralizar uma culpa coletiva. Foram necessários, a partir da segunda edição, revisões e um pós-escrito para eliminar algumas passagens mais duras ou mais difíceis de serem defendidas. Ela foi "impelida a reconsiderar e repensar" (Kohn, 2001, p. 15).

Registrar essa controvérsia tem como finalidade deixar claro que estamos entrando em uma discussão polêmica, envolvente e marcada por contradições. No entanto, gostaria de destacar que "Hannah Arendt não se reduz à banalidade do mal e ao processo Eichmann" (Kristeva, 2002, p.15) e que talvez a polêmica tenha sido "uma reação típica dos judeus alemães" (Correia, 2004, p. 88), tendo em vista principalmente a gravidade das afirmações e nem tanto algum erro de interpretação.

\section{O "homem na cabine de vidro": monstro ou palhaço?}

A personalidade de Adolf Eichmann foi um dos pontos mais controvertidos enfrentados por Hannah Arendt, que o considerava um novo tipo de criminoso, um hosti humani generis (inimigo do gênero humano), participante de um novo tipo de crime: assassinatos em massa num sistema totalitário. Esse novo tipo de criminoso só pode ser entendido a partir de uma nova profissão: o burocrata. Para um burocrata, a função que lhe é própria não é a de responsabilidade, mas sim a de execução (Correia, 2004, p. 93). Daí a reiterada afirmação burocrática: eu só cumpro ordens.

Esse foi o principal argumento de Eichmann: "Não sou o monstro que fazem de mim. Sou uma vítima da falácia" (Arendt, 1999, p. 269). O advogado de defesa trabalhou com a hipótese de que "sua culpa [de Eichmann] provinha de sua obediência, e a obediência é louvada como virtude. Sua virtude tinha sido abusada pelos líderes nazistas. Mas ele não era membro do grupo dominante, ele era uma vítima, e só os líderes mereciam punição" (idem, ibidem). Obviamente, os juízes, a promotoria, a imprensa nem Arendt estavam 
convencidos do argumento, mesmo que ele possa parecer plausível num primeiro momento.

Eichmann apresentou-se como um homem virtuoso - "minha honra é minha lealdade" (idem, p. 121) -e seu único erro teria sido o de obedecer ordens e seguir leis, pois ele sempre tomou o cuidado de agir conforme determinações superiores, comprovadas pelas normas legais (idem, p. 109). Eichmann agia dentro dos restritos limites que as leis permitiam e supostamente não entendia porque naquele tribunal era acusado de ser um criminoso. Para o réu, tudo não passava de um golpe de azar, pois tinha sido um bom cidadão, porém num Estado assassino. Sorte teria, em sua lógica, um bom cidadão num Estado justo.

De fato, Eichmann era um cumpridor de seus deveres; não se corrompia nem desrespeitava as normas vigentes; cumpria com eficiência o seu dever: encaminhar de maneira eficiente milhares de judeus para a morte. Hannah Arendt, ao enfatizar essas características do réu, procurava demonstrar a construção de uma personalidade condicionada e sem motivação aparente e, por isso mesmo, capaz das maiores barbaridades. "Eichmann [...] realizou o exercício da livre escolha como se fosse um animal condicionado, não agiu espontaneamente ou tomou iniciativa, ele evitou a responsabilidade e não julgou. Ele agiu como se fosse condicionado" (Kohn, 2001, p. 14). Outro traço marcante do réu era o seu apego às regras de bom comportamento, mostrando-se envergonhado e constrangido diante da lembrança de pequenos deslizes ou desobediências. Mesmo que as desobediências significassem salvar vidas humanas, Eichmann ficava visivelmente constrangido em admiti-las (Souki, 1998, p. 93).

Esses aspectos da personalidade de Eichmann levaram Hannah Arendt a se convencer de uma das afirmações do acusado: ele não era um monstro. Ao contrário, era um homem comum. E o mais assustador: tão comum quanto muitos outros. "O problema de Eichmann era exatamente que muitos eram como ele, e muitos não eram nem pervertidos, nem sádicos, mas eram e ainda são terrível e assustadoramente normais" (Arendt, 1999, p. 299).
Esta é a tese central da autora com o conceito de banalidade do mal. Arendt recusou de maneira firme qualquer explicação do nazismo que derivasse do comportamento moral dos indivíduos ou da sociedade alemã. Entender a personalidade daquele oficial nazista foi fundamental para Arendt negar qualquer ontologia ou patologia como teorias explicativas para o mal cometido.

\footnotetext{
Há alguns anos, em relato sobre o julgamento de Eichmann em Jerusalém, mencionei a “banalidade do mal”. Não quis, com a expressão, referir-me a teoria ou doutrina de qualquer espécie, mas antes a algo bastante factual, o fenômeno dos atos maus, cometidos em proporções gigantescas - atos cuja raiz não iremos encontrar em uma especial maldade, patologia ou convicção ideológica do agente; sua personalidade destacava-se unicamente por uma extraordinária superficialidade. (Arendt, 1993, p. 145)
}

A normalidade de Eichmann assustou Arendt e colocou-a em busca de outros modelos explicativos para o mal, para além do determinismo histórico e da distorção ideológica do nazismo, negando as teorias do mal como patologia, possessão demoníaca, determinismo histórico ou alienação ideológica. "Por trás desta expressão não procurei sustentar nenhuma tese ou doutrina, muito embora estivesse vagamente consciente de que ela se opunha à nossa tradição de pensamento - literário, teológico ou filosófico - sobre o fenômeno do mal" (Arendt, 1995, p. 5).

Assim, Arendt inicia um longo percurso para demonstrar que o mal não pode ser explicado como uma fatalidade, mas sim caracterizado como uma possibilidade da liberdade humana. Nesse sentido, ela demonstra o descompasso entre a personalidade comum do réu e as dimensões monstruosas do mal por ele perpetrado. Eichmann não era um monstro, ainda que os resultados de suas ações fossem monstruosamente macabros. Segundo psicólogos e sacerdotes que examinaram Eichmann, o seu comportamento "não é apenas normal, mas inteiramente desejável", "um homem de ideias muito positivas" (Arendt, 1999, p. 37). Essa era a revelação inesperada sobre aquele 
homem na cabine de vidro. Ele não era só normal, mas um bom pai de família, um filho exemplar e um irmão dedicado.

A ideia de burocratas assassinos como dedicados pais de família era - e ainda é - uma constatação difícil de ser aceita. Hannah Arendt confessou diversas vezes que ficou perplexa com essa realidade (Arendt, 1993, 1995, 1999). No entanto, ela preferiu trabalhar com essa hipótese ao invés de considerá-la infame ou peça de cinismo. Eichmann poderia muito bem ser apresentado como um burocrata dócil e um assassino eficiente.

O governo nazista seria uma organização burocrática cuidadosamente estruturada para absorver a solicitude do pai de família na realização de quaisquer tarefas que the fossem atribuídas e para dissolver a responsabilidade em procedimentos de extermínio em que o perpetrador de um assassinato era apenas a extremidade de um grupo de traba1ho. O pai de família, que despertaria em nós admiração e ternura em sua concentração no interesse dos seus, em sua consagração firme à mulher e aos filhos, em sua solicitude, preocupado basicamente com a segurança, teria se tornado um aventureiro. (Correia, 2004, p. 87)

A tarefa de Eichmann era organizar as deportações de judeus, levando-os diretamente para os campos de concentração. Era conhecido como um especialista na questão judaica.

O homem Eichmann era o perfeito instrumento para levar a cabo a "solução final": organizado, regular e eficiente tal qual a empreitada de que ele estava encarregado. $\mathrm{Na}$ sua função de encarregado de transporte, ele era normal e medíocre e, no entanto, perfeitamente adaptado ao trabalho que consistia em "fazer as rodas deslizarem suavemente", no sentido literal e figurativo. Sua função era tornar a "solução final" normal. [...] Eichmann representava o melhor exemplo de um assassino de massa que era, ao mesmo tempo, um perfeito homem de família. (Souki, 1998, p. 92)

Outra característica do réu chama a atenção de Hannah Arendt: a sua linguagem, mais especifica- mente a dificuldade de se expressar espontaneamente e os clichês.

Clichês, frases feitas, adesão a códigos de expressão e conduta convencionais e padronizados têm função socialmente reconhecida de nos proteger da realidade, ou seja, da exigência do pensamento feita por todos os fatos e acontecimentos em virtude de sua mera existência. Se respondêssemos todo tempo a esta exigência, logo estaríamos exaustos; Eichmann se distinguia do comum dos homens unicamente porque ele, como ficava evidente, nunca havia tomado conhecimento de tal exigência. (Arendt, 1995, p. 6)

Eichmann admitia suas dificuldades de expressão: "Minha única língua é o oficialês" (Arendt, 1999, p. 61). Hannah Arendt, ironicamente, registra "a luta heroica que Eichmann trava com a língua alemã, que invariavelmente o derrota" (idem, ibidem). Através do caso Eichmann, aprendemos "a lição da temível banalidade do mal, que desafia as palavras e o pensamento" (idem, p. 274). No seu repertório de frases feitas, Eichmann escondia-se na incomunicabilidade com o pensamento alheio. Ele era incapaz de pensar e entender o ponto de vista do outro (Kohn, 2001, p. 14). "Sua mente parecia repleta de sentenças prontas, baseadas em uma lógica autoexplicativa, desencadeada em raciocínios dedutivos, mas que, todavia, andavam em descompasso com o percurso da própria realidade" (Assy, 2001a, p. 139). As dificuldades de Eichmann com a fala despertaram a ironia de Hannah Arendt (idem, p. 67): "Apesar de todos os esforços da promotoria, todo mundo percebia que esse homem não era um 'monstro', mas era difícil não desconfiar que fosse um palhaço". "De minha parte, estava efetivamente convencida de que Eichmann era um palhaço: li com atenção seu interrogatório na polícia, de 3.600 páginas, e não poderia dizer quantas vezes ri, ri às gargalhadas!" (Arendt, 1993, p. 137). No entanto, Arendt (1999, p. 67) estava convencida de que "era essencial que ele fosse levado a sério".

Afinal, quem era o homem naquela cabine de vidro? Bom cidadão, leal, obediente, responsável, eficiente, regular, organizado, burocrata, comum, 
normal, banal, superficial, incapaz para o pensamento, acrítico, condicionado, desolado, desagregado, deslocado, fracassado, frio, não emotivo, calculista, vaidoso, ambicioso, medíocre, mentiroso, cínico, pervertido, sádico, inimigo do gênero humano, encarnação do nazismo, assassino ou monstro? São muitas as características que se poderia atribuir a Eichmann. De um polo a outro, Hannah Arendt enfatiza as marcas de caráter que se encontram no ponto mediano desses contrastes, isto é, o burocrata, comum, normal, banal e superficial. A percepção de que Eichmann era um homem comum, de superficialidade e mediocridade aparentes, deixou Hannah Arendt atônita, ao avaliar a proporção do mal por ele cometido. É a partir dessa percepção que ela formula a sua concepção de banalidade do mal.

\section{O mal sem motivos, sem raízes, sem explicações}

A controvérsia que Hannah Arendt traz para o campo do pensamento moral passa, sem dúvida, pela afirmação de que o mal é algo banal. O tema fica ainda mais complexo porque ela abandona a consagrada formulação kantiana de mal radical, defendida anteriormente.

Hannah Arendt discutiu o ineditismo do problema do mal no século XX em As origens do totalitarismo, em termos do mal radical. Subsequentemente retomou o tema do ineditismo do mal na vigência do totalitarismo na sua análise do caso Eichmann, expondo a sua visão sobre a banalidade do mal. (Lafer, 2003, p. 187)

Hannah Arendt formula um novo conceito e contraria uma tradição consolidada no pensamento moral da qual ela se considerava profundamente devedora. Lafer (idem, p. 188) e Souki (1998, p. 133) afirmam que há mais complementaridade do que oposição entre a concepção de mal radical discutida em As origens do totalitarismo e a novidade da banalidade do mal apresentada em Eichmann em Jerusalém. A meu ver, há evidências de que Arendt realmente abandona a concepção kantiana, ainda que recuse uma condição de teoria ou doutrina para o seu novo conceito. Isso fica claro na carta em resposta às críticas de Sholem:

É, sim, a minha opinião agora que o mal nunca é radical, que é apenas extremo e que não tem nem profundidade nem sequer uma dimensão demoníaca. Apenas o bem tem profundidade e pode ser radical [...]. De fato você tem razão, eu mudei de opinião e não falo mais de mal radical. (Arendt apud Souki, 1998, p. 101)

O objetivo deste artigo não é analisar os movimentos que levaram Arendt a essa mudança conceitual. ${ }^{2} \mathrm{O}$ que importa é registrar que Hannah Arendt estava convencida de que o mal não tem raízes, não tem profundidade. $\mathrm{O}$ mal "é como um fungo, não tem raiz, nem semente" (Kohn, 2001, p. 14), mas espalha-se sobre uma superfície específica, a massa de cidadãos inaptos para a capacidade de pensar e incapazes de dar significado aos acontecimentos e aos próprios atos (Assy, 2001a, p. 152). Em Eichmann em Jerusalém, o mal não é radical, mas pode ser extremo; ele é superficial, ainda que suas consequências sejam incalculavelmente desastrosas e monstruosas (Souki, 1998; Assy, 2001b).

É importante notar também que a banalidade do mal está circunscrita a um tipo de personalidade, tipificada em Eichmann. "Ele não era particularmente estúpido, nem moralmente insano, nem criminosamente motivado, nem ideologicamente antissemita, nem em qualquer sentido psicologicamente "anormal" (Kohn, 2001, p. 15). Eichmann não é um assassino convicto. O mal encontrado nele é banal porque não tem explicação convincente, não tem motivação alguma, nem ideológica, nem patológica, nem demoníaca. Por isso, Hannah Arendt diz-se "vagamente consciente" (Arendt, 1995, p. 5) de que seu novo

1 Esse mesmo trecho da carta aparece em Watson (2001, p. 82).

${ }^{2}$ Para entender a relação entre o mal radical e a banalidade do mal no pensamento de Arendt, veja, em especial, os trabalhos de Bernstein $(2002,2004)$ 
conceito contradiz nossa tradição de pensamento sobre o fenômeno do mal.

\begin{abstract}
A questão do mal não é, assim, uma questão ontológica, uma vez que não se apreende uma essência do mal, mas uma questão da ética e da política. [...] O problema do mal sai, verdadeiramente, dos âmbitos teológico, sociológico e psicológico e passa a ser focado na sua dimensão política. (Souki, 1998, p. 104)
\end{abstract}

O novo conceito de Hannah Arendt apresenta um mal sem inspiração própria, porém não menos monstruoso em suas consequências. Esse abismo entre a gravidade dos atos e a superficialidade das motivações a leva a cunhar um novo significado para a banalidade (Assy, 2001b). Lechte (2002, p. 206) afirma que a banalidade do mal se tornou uma das mais famosas conceituações arendtianas, porque conseguiu perceber que o ineditismo do mal efetivado pelo nazismo era, além de monstruoso, banal e burocrático e, ao mesmo tempo, sistemático e eficiente. Assy (2001a, p. 87) e Souki (idem, p. 12) também concordam que, diante do mal como fenômeno surgido a partir da experiência totalitária, burocraticamente eficiente, Hannah Arendt é levada a pensar sobre um mal sem precedentes e desconhecido. Para esse mal, não há modelos nem padrões - políticos, históricos, teológicos, psicológicos ou filosóficos - de entendimento. "Todavia nem sequer temos uma palavra para o que estamos nos referindo" (Arendt apud Assy, 2001a, p. 88), registrou em manuscritos de 1966. No entanto, ela estava consciente do "desamparo que os juízes experimentaram quando se viram confrontados com a tarefa de que menos podiam escapar, a tarefa de entender o criminoso que tinham vindo julgar" (Arendt, 1999, p. 299).

Hannah Arendt estava diante de um fenômeno inédito e para isso procurou cunhar um novo modelo de entendimento. Assim, ela inicia, por força de tantas reações, vários esclarecimentos. Vale a pena aqui retomar ao menos dois: 1) a banalidade de Eichmann não significa a sua inocência; e 2) banalidade não significa normalidade.
Primeiro, a expressão banalidade do mal não quer ser uma justificativa para as monstruosidades de Eichmann nem significa que Arendt negligencie a imputabilidade do réu (Assy, 2001b). Hannah Arendt estava convencida de que Eichmann era responsável pelos seus crimes e deveria ser punido. Ao descrever Eichmann como banal, ela não visava torná-lo menos imputável, "não estava buscando isentá-lo dos atos ilícitos que efetivamente cometeu, mas compreender o tipo de mentalidade que poderia contribuir para o surgimento de indivíduos como ele" (Correia, 2004, p. 95). O conceito de banalidade não quer abrir precedentes para uma suposta inocência do réu, mas tão somente entender um fenômeno.

Segundo, banalidade não quer significar algo sem importância, tampouco algo que possa ser assumido como normal. Em sua resposta a Sholem, Hannah Arendt afirma que banalidade não significa uma bagatela nem uma coisa que se produza frequentemente (Souki, 1998, p. 103). Arendt distingue banal de lugar-comum (Assy, 2001a, p. 143). Lugarcomum diz respeito a um fenômeno que é comum, trivial, cotidiano, que acontece com frequência, com constância, com regularidade. Banal, por sua vez, não pressupõe algo que seja comum, mas algo que esteja ocupando o espaço do que é comum. Um ato mau torna-se banal não por ser comum, mas por ser vivenciado como se fosse algo comum. A banalidade não é normalidade, mas passa-se por ela, ocupa indevidamente o lugar da normalidade. "O mal por si nunca é trivial, embora ele possa se manifestar de tal maneira que passe a ocupar o lugar daquilo que é comum" (Assy, 2001a, p. 144).

Mas como o mal pode tornar-se banal? Como a monstruosidade dos assassinatos em massa puderam tornar-se fatos corriqueiros, trivializados, como se fossem comuns? Como o mal pôde ocupar o lugar da normalidade e esconder o seu próprio horror?

Para responder a essas questões, recorro a duas características que Arendt aponta para a sociedade de massas: a superficialidade e a superfluidade. Podemos esclarecer, ainda que de maneira breve e preliminar, que o mal se torna banal porque os seus agentes são 
superficiais e suas vítimas são consideradas supérfluas. "Quanto mais superficial alguém for, mais provável será que ele ceda ao mal. Uma indicação de tal superficialidade é o uso de clichês, e Eichmann era um exemplo perfeito" (Assy, 2001a, p. 145). Quanto à superfluidade da vida humana, Arendt (1989, p. 510) afirma que este tem sido um fenômeno decorrente do sentido extremamente utilitário das sociedades de massa:

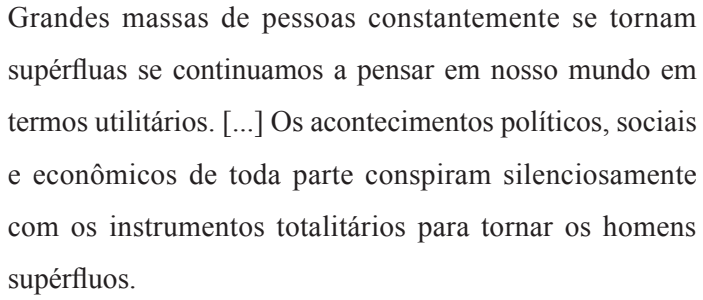

Para além da defesa do argumento de Arendt, não há como negar que o conceito de banalidade do mal revela a sua imprecisão ao lidar com um fenômeno surpreendente.

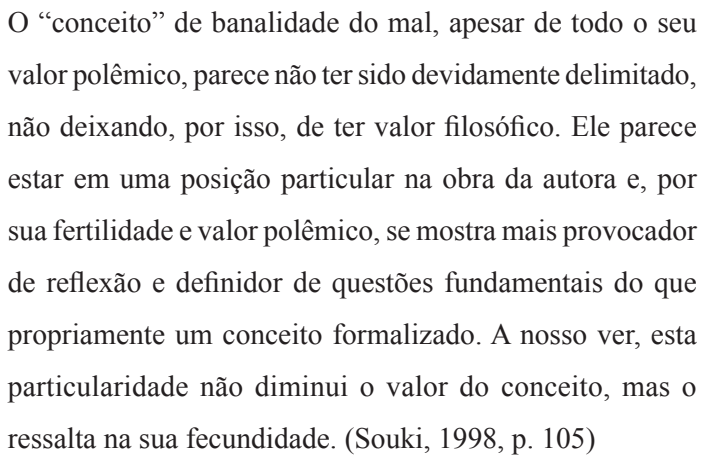

\section{A banalidade do mal e suas implicações morais}

O julgamento de Eichmann envolvia mais do que constrangimentos jurídicos. A maior polêmica estava na análise sobre a capacidade humana de julgar, isto é, aquela faculdade que permite discernir sobre o que é certo e errado. Hannah Arendt (2004, p. 288) demonstrou, mais de uma vez, sua perplexidade diante do fato de que desastrosamente quase todos os homens em alta posição pública - e em alguns casos com sólida formação moral, como o papa Pio XII e o rabino Leo
Baeck - tinham fracassado em compreender o verdadeiro significado do nazismo na Alemanha.

O julgamento de Eichmann não proporcionou a ela somente o entendimento sobre aquele burocrata banal na cabine de vidro, mas também a possibilidade de repensar as tradicionais formas de entender a nossa formação moral, quase sempre baseadas na convicção de que os valores morais devem ser fortemente difundidos através de conteúdos específicos e como um antídoto ao mal. Arendt não parece convencida de que a simples difusão voluntarista de conhecimentos morais será condição suficiente e necessária para a escolha e a prática do bem. A possibilidade que sua reflexão nos oferece é para além da educação moral através de conteúdos moralizantes, mas uma abertura para uma prática marcada pelo pensamento, como tentarei demonstrar adiante.

Nesse sentido, duas indagações são motivadoras e estão implícitas na tentativa de Arendt em entender o totalitarismo e o fenômeno que Eichmann tão bem exemplifica. Primeiro: Por que aconteceu? Segundo: Como foi possível acontecer? Essas questões nascem da perplexidade diante do fenômeno que ela vivenciou e foi obrigada a pensar. Arendt buscou respondê-las amplamente, com incursões no campo da economia, da teoria política, das estratégias militares e da jurisprudência. Interessam-me aqui as repostas formuladas no campo da moral e suas implicações para repensar a educação em valores.

Vale a pena retomar que o verdadeiro horror do totalitarismo está "no profundo servilismo de seus agentes, não em nenhuma explicação psicológica profunda ou qualquer vontade política vertiginosa" (Lechte, 2002, p. 207). De fato, o servilismo - como o valor supostamente moral da obediência - foi constatado por Hannah Arendt não só naquele réu intrigante, mas em todas as formas sociais de totalitarismo. A obediência como virtude foi a base da condição verdadeiramente abjeta da possibilidade do nazismo enquanto um modelo de assassinatos em massa.

Hannah Arendt buscou fugir da controvérsia sobre se o nazismo fazia ou não parte do caráter do povo alemão, pois ela achava que havia usos abusivos 
do termo. Dessa forma, é válido afirmar que ela não atribuía ao caráter de um povo, em sua globalidade, alguma característica específica. No entanto, também é verdade que ela se impressionou muito com o adesismo inquestionável de parcelas significativas da sociedade alemã, mesmo aquelas altamente formadas nos princípios morais mais sofisticados. O que tudo indica é que, no caso do nazismo alemão, o alto nível instrucional de boa parte da sociedade e as especulações filosóficas mais sofisticadas sobre ética e moral de alguns eminentes pensadores alemães não foram suficientemente fortes para conter a barbárie que se instaurou. A terrível e simples verdade era que o nacional-socialismo tinha aprovação da maioria da sociedade alemã: "A situação era tão simples quanto desesperada: a esmagadora maioria do povo alemão acreditava em Hitler" (Arendt, 1999, p. 114), por mais educada e moralmente formada que fosse essa sociedade.

É óbvio que havia oposições a Hitler. Aqueles que eram contra o nazismo apontavam a catástrofe do regime e o fracasso moral da sociedade alemã. No entanto, eles não tinham nem plano nem intenção de efetivar uma oposição consistente. No que se refere à situação dos judeus, Arendt (idem, p. 126) ainda é mais crítica sobre o papel dos oposicionistas ao regime:

\footnotetext{
Muitas vezes se disse que a asfixia dos doentes mentais teve de ser suspensa na Alemanha por causa dos protestos da população e de uns poucos dignitários corajosos das igrejas; no entanto, nenhum protesto desse tipo foi feito quando o programa voltou-se para a asfixia de judeus, embora alguns centros de extermínio estivessem localizados no que era então território alemão, cercados por populações alemãs.
}

Sobre o papel da oposição a Hitler, Arendt (idem, p. 116) é categórica: aqueles que se opuseram a Hitler foram corajosos, mas a coragem deles "não foi inspirada por indignação moral ou por aquilo que sabiam que outras pessoas tinham sofrido; eles foram motivados quase exclusivamente por sua certeza da iminente derrota e ruína da Alemanha". As divergências com Hitler dentro da Alemanha foram quase sempre por questões políticas ou militares, e não por convicções morais.
Entre os líderes da resistência alemã, havia antissemitas convictos, que não discordavam do Terceiro Reich no que diz respeito ao tratamento dispensado aos judeus. Se Arendt se esquivou do debate sobre se o servilismo fazia parte ou não do caráter do povo alemão, o mesmo não se observa quando o tema é o apego à mentira $\mathrm{e}$ ao autoengano. Ela (idem, p. 65) afirma que "ainda é difícil às vezes não acreditar que a hipocrisia passou a ser parte integrante do caráter nacional alemão".

Em um de seus mais famosos discursos, Hitler bradava aos soldados: "Atrás de nós marcha a Alemanha!" Talvez fosse pura retórica, a fim de animar as tropas, mas, segundo Arendt, tudo leva a crer que, se atrás do Führer não marchavam 80 milhões de soldados, ao menos caminhava silenciosa a maioria esmagadora dos alemães, bem educados e moralmente formados nos princípios mais elevados da religião e da filosofia ocidentais. A omissão da boa sociedade foi a permissão necessária para a marcha nazista. Tendo em vista essa maioria silenciosa - e também os seis milhões de judeus assassinados - é que Arendt (idem, p. 268) classifica o Holocausto como um crime de massas, ${ }^{3}$

[...] pois estes crimes foram cometidos em massa, não só em relação ao número de vítimas, mas também no que diz respeito ao número daqueles que perpetraram o crime e à medida que qualquer dos criminosos estava próximo ou distante do efetivo assassinato da vítima nada significa no que tange à medida de sua responsabilidade

Vale a pena lembrar que Hannah Arendt considera a massa assassina como assustadoramente normal e desprovida da capacidade de pensar. Segundo Souki (1998, p. 61), uma sociedade torna-se cúmplice da demência totalitária do Estado na medida em que partilha as mentiras do sistema não por ser enganada, mas por se recusar a perscrutar a verdade dos fatos.

\footnotetext{
${ }^{3} \mathrm{O}$ controvertido conceito arendtiano de crime de massas é
} um dos temas mais comentados pela literatura especializada. Veja, por exemplo, Correia (2004, p. 94), Assy (2001a, p. 87), Souki (1998, p. 61) e Lafer (2003, p. 136). 
Para Lafer (2003, p. 136), a cumplicidade da massa circunstante foi fundamental para o êxito do nazismo, pois tornava a solução final normal, isto é, a sociedade alemã conferia, por sua omissão, caráter de normalidade aos assassinatos em massa.

Quanto ao povo judeu, Hannah Arendt apresenta basicamente duas críticas: a falta de reação e a conivência dos conselhos de judeus com as políticas nazistas. Com relação à primeira crítica, ela a considerava erroneamente tratada no julgamento, pois dava margem a entendimentos de que a não beligerância das vítimas diminuísse em algo a responsabilidade dos assassinos. Para Arendt (1999), o tema foi trazido ao tribunal tão somente para marcar a diferença entre o heroísmo israelense e a passividade dos judeus europeus. Quanto à segunda crítica, é importante registrar que havia muitas divisões entre os judeus europeus. Havia pensamentos divergentes no que tange a como deveria ser o relacionamento dos judeus com os Estados nacionais. Entre ortodoxos, sionistas e assimilados, estes últimos eram os mais desorganizados e discriminados pelos próprios judeus. Os conselhos de judeus, dominados por sionistas e ortodoxos, "acreditavam que se era uma questão de selecionar judeus para a sobrevivência, os próprios judeus é que deviam fazer a seleção" (Arendt, 1999, p. 75), com claros prejuízos para os assimilados. De fato, os oficiais do Terceiro Reich deram aos conselhos de judeus a incumbência de organizar as listas de deportação e dos que deveriam ir para os campos de concentração, organizando inclusive uma polícia judaica. Para Arendt, essa situação levou a maioria dos judeus a ter dois inimigos objetivos: as autoridades nazistas e as autoridades judaicas. Para Young-Bruehl (1997, p. 302), Arendt não dedica mais do que 12 páginas, em meio a 300, para refletir sobre a passividade dos judeus assimilados e as responsabilidades das autoridades judaicas. Mas foram, sem dúvida, essas 12 páginas que a levaram para o meio de um turbilhão de críticas, difamações, ataques e inimizades. ${ }^{4}$

\footnotetext{
${ }^{4}$ Não podemos esquecer que o contato pessoal e profissional que Hannah Arendt manteve, no período pós-guerra, com Martin
}

As críticas de Hannah Arendt ao comportamento moral de judeus e alemães tiveram como objetivo desconstruir algumas argumentações vigentes à época, que tentavam explicar o fracasso moral vivenciado na Europa daqueles tempos sombrios. Dentre tais argumentações, destacarei três: 1) a teoria da peça de engrenagem; 2) a teoria da culpa coletiva; e 3) a teoria da voz da consciência.

A teoria da peça de engrenagem foi utilizada tanto pela defesa de Eichmann quanto pela acusação. Segundo a defesa, Eichmann era apenas uma pequena engrenagem na maquinaria chamada solução final para a questão judaica. A promotoria, seguindo a mesma lógica, via naquele homem não uma engrenagem, mas o motor do Holocausto. Para Arendt, aquele homem tolo, sem iniciativas, de mediocridade e superficialidade aparentes, um oficial subalterno, que sempre agia ancorado por leis e memorandos, não era motor de coisa alguma. No entanto, ela estava de acordo que, para as ciências políticas, era importante entender que "a essência do governo totalitário, e talvez a natureza burocrática, seja transformar homens em funcionários e meras engrenagens, assim os desumanizando" (Arendt, 1999, p. 312). Hannah Arendt também estava convencida do fato de Eichmann pertencer a uma estrutura organizacional e de que poderia ser trocado, como uma peça, por outro burocrata qualquer, que faria a mesmíssima coisa em seu lugar, pois afinal não se tratava de uma maldade específica (demoníaca, patológica ou ideológica), mas do cumprimento de funções de Estado. Tal realidade não desresponsabilizava, em hipótese alguma, essa pequena engrenagem dos atos monstruosos que foram cometidos. Na medida em que a pequena engrenagem comete crimes, num tribunal sua ação deve ser julgada como uma ação supostamente criminosa até que se prove o contrário,

Heidegger, que chegou a ser reitor da Universidade de Freiburg entre 1933 e 1934, com apoio do Partido Nacional Socialista, também foi um dos motivos das campanhas difamatórias de setores da intelectualidade judaica contra ela. Sobre isso, veja o trabalho de Ettinger (1996). 
pois Eichmann, como qualquer outro burocrata, tinha, sim, responsabilidades, pois tinha a possibilidade de escolha, inerente à sua condição humana. Ainda que levasse em conta tal teoria, a tentativa da defesa era estupidamente equivocada, pois seria difícil, senão impossível, encontrar atenuantes para os seus crimes. A fidelidade ao trabalho realizado, tantas vezes declarada pelo réu, era um agravante. Se ele se tivesse apresentado à corte dizendo que era obrigado a fazer o que fazia, mas procurava não cumprir plenamente as ordens recebidas a fim de salvar vidas, ele ainda assim seria responsável, mas talvez pudesse contar com alguns atenuantes. Porém Eichmann dizia-se um cumpridor fiel das ordens, que seu ideal de vida era cumprir seu dever e fazer seu trabalho com precisão e eficiência e, ainda mais, sentia-se envergonhado quando no tribunal era levado a admitir que não cumpria algumas ordens recebidas, ainda que essa desobediência tivesse significado salvar centenas de vidas humanas. "A 'teoria da engrenagem', ainda que possa ser útil à ciência política, passa à margem da questão da responsabilidade pessoal" (Correia, 2004, p. 94). E esse era um tema ético central para Hannah Arendt (2004, p. 87), pois a responsabilidade pessoal não pode ser transferida para um sistema, ainda que se trabalhe sob uma ditadura. Ao rebater essa teoria, a autora insiste na liberdade que caracteriza fundamentalmente a ação humana, que funda e exige toda e qualquer formação moral.

A teoria da culpa coletiva surgiu no julgamento pela declaração de inocência do acusado, que buscava a absolvição jurídica assumindo publicamente suas supostas falhas morais. A defesa havia declarado: "Eichmann se considera culpado perante Deus, não perante a lei" (Arendt, 1999, p. 32). No tribunal, Eichmann declarou-se "inocente no sentido da acusação", mas também disposto a "ser enforcado publicamente como exemplo para todos antissemitas da terra" (idem, p. 36). A vocação de Eichmann para o martírio revelou-se depois de ele saber que setores da juventude alemã, motivados possivelmente pela repercussão dos resultados dos julgamentos de Nuremberg, se sentiam culpados pelo Holocausto. No entanto, aqueles jovens nada tinham a ver com a guerra. Para Correia (2004, p. 93), "[...] é importante distinguir entre culpa e responsabilidade, tanto porque muitos se sentem culpados sem terem qualquer envolvimento, como por muitos serem responsáveis sem se sentirem culpados - enquanto os efetivamente responsáveis que se sentem culpados são muito poucos".

Para Arendt, a culpabilidade é algo individual, por isso passível de penalidades jurídicas. Já “a responsabilidade coletiva é mais um termo da categoria política do que jurídica ou moral" (Souki, 1998, p. 90). Arendt faz então uma distinção entre culpa (individual) e responsabilidade (coletiva), por considerar que "onde todos são culpados, ninguém é” (Correia, 2004, p. 93), ou seja, se todos têm culpa, ninguém efetivamente pode ser julgado. Se ninguém pode ser julgado, ninguém é imputável pelos crimes. No entanto, ela não negligencia a atribuição de culpabilidade ao réu pelo fato de ele não ser o único responsável por aquilo que fazia. Quanto à responsabilidade coletiva, ela afirma que ainda faltava ao povo alemão uma definitiva demonstração pública de responsabilidade pelos crimes cometidos em seu nome (Assy, 2001b). Assumir essa responsabilidade coletivamente teria efeitos políticos e morais, mas, obviamente, não poderia ser passível de penalidades jurídicas. Mais uma vez, a autora argumenta a favor da condição humana, enquanto qualidade de ser livre e único, por isso mesmo responsável por seus atos e pelas consequências deles.

A terceira teoria - a voz da consciência - questionava se Eichmann tinha consciência do que estava fazendo. Para Arendt (1999, p. 45), o réu "não tinha tempo, e muito menos vontade de se informar adequadamente, jamais conheceu o programa do Partido [Nacional Socialista], nunca leu Mein Kampf". O ponto mais importante não é sobre a consciência no sentido de ter conhecimento do que efetivamente era o nazismo, em suas ideologias e programas. O ponto fundamental é se Eichmann podia ouvir essa voz que chamamos de consciência, se ele podia acessar um conjunto de valores morais que lhe informasse sobre o horror do qual ele fazia parte. Se ele era perturbado por esse outro que nos habita, que às vezes somos nós 
mesmos e outras vezes um outro moralmente significativo que nos fala. Hannah Arendt estava convencida de que a resposta era sim, pois Eichmann declarou várias vezes que estava com a consciência tranquila, pois cumprira seu dever e sabia que era isso que deveria fazer. Sabe-se que a voz da consciência não é algo dado naturalmente, mas sim algo construído coletiva e intersubjetivamente.

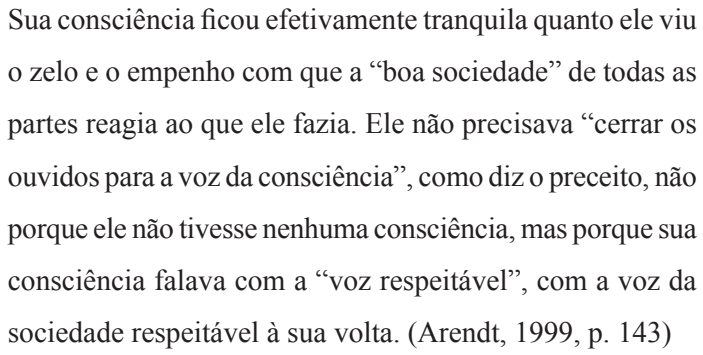

A voz respeitável da boa sociedade esteve presente no tribunal na pessoa de Heinrich Grüber, um ministro protestante. O pastor Grüber "pertencera ao grupo numericamente pequeno e politicamente irrelevante de pessoas que se opuseram a Hitler por princípio e não por considerações nacionalistas e cuja posição na questão judaica era inequívoca" (idem, p. 146). O advogado de defesa fez-lhe uma pergunta altamente pertinente: "O senhor tentou influenciá-lo? Tentou, como religioso, apelar para os sentimentos dele, fazer um sermão para ele e lhe dizer que sua conduta era contrária à moralidade?" (idem, p. 148). As respostas embaraçosas do pastor indicavam que ele não havia sido uma voz consciente de alerta ou empecilho às atitudes de Eichmann, mas que tinha sido mais uma voz respeitável com sinais claros de cumplicidade. Tão significativo quanto à pergunta da defesa foi o depoimento de Eichmann: "Ninguém veio até mim e me censurou por nada no desempenho de meus deveres, nem o pastor Grüber disse uma coisa dessas. Ele veio até mim e pediu alívio para o sofrimento, mas não objetou de fato o desempenho de meus deveres enquanto tais" (idem, ibidem). A teoria da voz da consciência também deve ser rebatida com os argumentos apresentados anteriormente sobre a condição humana marcada pela liberdade de ação e pela culpabilidade pessoal e a responsabilidade coletiva. Grüber era moralmente responsável. Eichmann, juridicamente culpado, um criminoso. Dentro de determinadas condições, eles agiram humanamente, o que significa dizer com algum nível de liberdade de escolha. Nesse sentido, o fato de Eichmann ter participado do assassinato de milhares de judeus, ainda que com a aceitação e a respeitabilidade da boa sociedade, fazia dele um criminoso, e por isso ele devia ser punido.

O caso Eichmann representou um fenômeno sobre o qual Hannah Arendt se debruçou em várias outras oportunidades. Não só porque ela foi impelida a repensar o conceito de banalidade do mal, devido às críticas recebidas, mas pela perplexidade que o tema lhe causara. O fato de ela retornar ao caso Eichmann em diferentes momentos demonstra três preocupações recorrentes: 1) entender a mentalidade de um novo tipo de criminoso; 2) alertar para a possibilidade de repetição do fenômeno testemunhado como inédito; e 3 ) discutir as possibilidades de evitá-lo.

Vale o alerta de Arendt (1999, p. 295-296) sobre a possibilidade bastante incômoda, mas inegável, de que crimes similares possam ser cometidos no futuro:

\footnotetext{
Faz parte da própria natureza das coisas humanas que cada ato cometido e registrado pela história da humanidade fique com a humanidade como uma potencialidade, muito depois de sua efetividade ter se tornado do passado. Nenhum castigo jamais possuiu poder suficiente para impedir a perpetração de crimes. Ao contrário, a despeito do castigo, uma vez que um crime específico apareceu pela primeira vez, sua reaparição é mais provável do que poderia ter sido a sua emergência inicial.
}

Se o castigo não pode impedir a banalidade do mal de emergir novamente em nossa história, o que, então, poderia? A resposta arendtiana é instigante e talvez uma pista para os que querem repensar a educação moral. Seguirei, então, a hipótese que ela mesma traçou, em $A$ vida do espírito (Arendt, 1995, p. 6), para tentar responder a essa questão: 
Seria possível que a atividade do pensamento como tal - o hábito de examinar o que quer que aconteça ou chame a atenção independente de resultados e conteúdo específco - estivesse dentre as condições que levam os homens a se abster de fazer o mal, ou mesmo que ela realmente os "condicione" contra ele?

\section{O vazio do pensamento e a tarefa educativa}

Como demonstrado com os argumentos arendtianos, as barbáries cometidas por Eichmann não se fundamentam na inveja, no ódio, na cobiça nem mesmo na estupidez (desconhecimento), mas sim na irreflexão. Essa é hipótese central de Hannah Arendt em $A$ vida do espírito (Arendt, 1995). Nessa obra, ela delineia a relação entre a banalidade do mal e o vazio do pensamento (Pessoa, 1998).

O que deixou Hannah Arendt mais impressionada foi a superficialidade de Eichmann. Aquele homem não era monstruoso, enfermo ou demoníaco; nele também não se encontravam grandes convicções ideológicas ou partidárias. Entre todas as características daquele estranho réu em Jerusalém, a mais determinante para explicar seu comportamento era a sua incapacidade para o pensar. O que tornava Eichmann uma aberração era o fato de ele nunca haver experimentado as exigências do pensamento diante dos acontecimentos. A questão que a filósofa se propõe a aprofundar, então, é a ausência do pensamento e sua possível relação com os atos maus (Duarte, 2000).

O primeiro volume da obra $A$ vida do espírito busca entender o estatuto do pensamento. No entanto, a motivação inicial é o julgar. O ponto de partida do livro está profundamente marcado pelas preocupações da autora com a faculdade do juízo. No clássico ensaio Pensamento e considerações morais, ela, motivada pelo caso Eichmann, já se perguntava: "Será que nossa capacidade de julgar, de distinguir o certo do errado, o belo do feio depende de nossa capacidade de pensar?" (Arendt, 1993, p. 146).

Em $A$ vida do espírito, Hannah Arendt desqualifica as tradicionais explicações sobre o que motiva o ato mau (patologia psicológica, possessão demoníaca, alienação ideológica, determinismo histórico ou desconhecimento de causa) e apresenta como possível alternativa a ausência do pensamento (Pessoa, 1998; Duarte, 2000). Nessa perspectiva, ela examina a relação entre o pensamento e o juízo. A sua proposição é que a incapacidade de pensar oferece um ambiente privilegiado para o fracasso moral. A hipótese de Arendt é que o ato de pensar poderia - pois não há garantias ou certezas - condicionar os seres humanos a não praticar o mal. Nesse sentido, o pensamento, na concepção arendtiana, traz em si mais possibilidades do que seguranças ou determinações. Algumas dessas possibilidades seriam os efeitos liberadores do pensamento sobre o juízo e os efeitos preventivos no que se relaciona ao fenômeno do mal (Assy, 2004, p. 165). Daí a minha aposta, neste trabalho, de relacionar a banalidade do mal, o vazio do pensamento e os imperativos de uma tarefa educativa que se queira moral.

Arendt (1995, p. 98-107) revisita a tradição metafísica sobre o estatuto do pensamento e busca as respostas ao longo da história da filosofia para a questão: $O$ que é o pensar ${ }^{5}$ A perspectiva histórica apresenta, na releitura de Arendt, clara oposição entre o mundo da ação e o mundo do pensamento, ou seja, na tradição metafísica, o pensamento sempre foi marcado pela quietude, pela contemplação e pela passividade. Hannah Arendt reconhece que a tradição, ao tratar da passividade do pensamento, aponta para uma importante característica do pensar (Pessoa, 1998, p. 42). Assim, a tradição, mesmo que nebulosamente, toca no polêmico tema da incompatibilidade entre o agir no mundo e o ato de pensar. Mas, para além dessa primeira e mais conhecida visão sobre o pensar, Arendt (idem, p. 8) quer investigar o pensamento como atividade, como a mais pura atividade humana: "Nunca um

${ }^{5}$ Desde que havia escrito A condição humana (Arendt, 2001), obra na qual analisa especificamente as questões relacionadas à vida ativa, Hannah Arendt buscava entender como o pensamento - $a$ vida contemplativa - tinha sido compreendido pelas distintas tradições filosóficas. 
homem está mais ativo do que quando nada faz, nunca está menos só do que a sós consigo mesmo".

Inicialmente, Arendt (idem, p. 55) acata a concepção metafísica de que o pensamento é uma saída - e não subterfúgio - do mundo. No entanto, para ela, isso nada teria a ver com fuga do mundo e dos seus problemas, até porque esse tipo de interpretação entraria em contradição com as suas concepções em filosofia política (Arendt, 1993). Essa saída do mundo seria, então, a capacidade de romper com o cotidiano, uma descontinuidade própria da vida humana, uma parada, uma re-flexão, o ato de voltar-se sobre os acontecimentos a fim de dar significados a eles. E é isso que Eichmann não tinha; ele vivia num mundo de contínuos clichês. A atividade de pensar significa rompimento com o mundo, mas não é trocar esse mundo por um melhor, mais puro ou mais profundo (Arendt, 1995), como erroneamente indicou a tradição metafísica.

Apesar de romper com a tradição, principalmente quando ela dá um estatuto ontológico ao mundo invisível, Arendt (idem, p, 57) reconhece que os metafísicos descobriram algo muito importante: "pensar é estar fora do mundo". Essa retirada é uma distração total. É como se a experiência do pensamento se originasse numa sensação de estranhamento, principalmente com as coisas mais cotidianas.

Se, como Eichmann, homens e mulheres em tempos sombrios experimentam o fracasso moral e se esse fracasso se relaciona com a incapacidade de pensar, com a incapacidade de retirar-se do mundo e significá-lo, então poderíamos agora perguntar: Poderia a educação ser propícia ao pensamento enquanto estranhamento das coisas cotidianas? Se o que está em crise é a maneira como tradicionalmente pensamos e não a nossa capacidade de pensar, então é provável que haja um tipo de educação que seja possível na perspectiva do rompimento e da significação?

A meu juízo, a educação moral ou educação em valores deve ajudar a desfazer as continuidades irrefletidas existentes entre o mundo cotidiano e o mundo dos clichês, no qual podemos, com perigosa facilidade, habitar. Uma educação em valores, então, poderia incorporar em sua prática tanto uma denúncia à banalidade, enquanto mal sem motivos, quanto um anúncio das responsabilidades morais diante do estranhamento necessário com o mundo cotidiano. A perspectiva arendtiana revelaria, assim, a crise do pensamento metafísico, garantiria a autonomia do âmbito do pensamento enquanto campo específico da vida do espírito e indicaria as possibilidades de uma educação que se relacione com o pensamento. Esta quer ser a aposta mais firme deste artigo.

Não é minha intenção neste trabalho oferecer um projeto pedagógico contra a banalidade do mal, mas tão somente - se é que isso seja pouca coisa - refletir sobre alguns fundamentos para a tarefa educativa que se queira comprometida com o respeito e a abertura aos valores morais mais fundamentais, como justiça, igualdade, liberdade, solidariedade, diálogo e tolerância.

A perspectiva inovadora de Hannah Arendt sobre o estatuto do pensamento ajuda a entender a banalidade do mal que uma educação em valores - e por isso mesmo moral - deve enfrentar. Mais importante, no entanto, será pensar tais fundamentos numa perspectiva assertiva. Assim, considerando o estatuto do pensamento revisitado por Arendt (1995), retomo três contribuições que considero centrais para o campo da educação moral.

Em primeiro lugar, não se pode esquecer de que Hannah Arendt quer entender se existe alguma relação entre a incapacidade de pensar - o não estar atento aos fatos, às coisas e aos significados do mundo - e a prática do mal (Assy, 2001a; Souki, 1998). Eichmann é seu bizarro exemplo. No entanto, Eichmann não é um caso episódico; ele é apenas modelar para tantos de nós.

Em segundo lugar, é mister ter presente as fronteiras e as diferenças que Hannah Arendt apresenta entre pensar e conhecer; entre a atividade do significado e a pretensa atividade da verdade. Conhecer é a busca do intelecto pela verdade. O conhecimento cumpre sua finalidade alcançando resultados que podem ser acumulados. O pensamento não busca a verdade; ele lida com os significados, com os sentidos atribuídos 
ao mundo, aos fatos, às pessoas. $\mathrm{O}$ pensamento não se interessa pela verdade das coisas, mas sim pelo que elas significam para nós (Arendt, 1995, p. 42-51). Está claro, a meu juízo, que Hannah Arendt quer marcar uma distinção entre pensar e estar no mundo, ou seja, entre pensar e dominar o mundo pelo conhecimento meramente instrumental. O pensamento é uma abertura que se caracteriza por ir além da atividade de conhecer, de manipular, de instrumentalizar o mundo. O conhecimento deixa um rastro: o saber que pode ser acumulado (idem, ibidem). Em contrapartida, podemos dizer que o pensamento nos deixa de mãos vazias; ele não tem poder de acumular significados, pois os significados são experiências únicas e irreproduzíveis. Assim, quanto aos resultados, o pensamento está liberado dos interesses da acumulação, e, quanto à finalidade, ele é significativo e desvencilhado da chamada verdade neutra e objetiva. O pensamento, na concepção arendtiana, não pretende uma aproximação manipuladora tal como o conhecimento - com as coisas do mundo, mas busca os sentidos de cada coisa ser no mundo. " $\mathrm{O}$ pensamento retira-se - radicalmente e por sua própria conta - deste mundo e de sua natureza evidencial, ao passo que a ciência se beneficia de uma possível retirada em função de resultados específicos" (idem, p. 44). Daí parece claro que uma educação moral não deve estar preocupada apenas com conteúdos moralizantes a serem incluídos no currículo escolar. Na perspectiva arendtiana, uma educação que se queira moral deve, sobretudo, apostar - sem garantias ou certezas - no pensamento enquanto exercício de descontinuidade com o cotidiano e significação do mundo.

Em terceiro lugar, retomo uma importante afirmação de $A$ vida do espírito: "ser e aparecer coincidem" (idem, p. 17). Arendt (idem, p. 18) rejeita o dualismo entre as aparências e as essências, bem como o desprezo dos filósofos pelas coisas do mundo. Aqui ficam claras as opções de Arendt pela fenomenologia e seu estratégico afastamento das ontologias morais. Para ela, ser percebido e reconhecido pelos sentidos do outro - ou seja, aparecer - é a condição básica para algo garantir sua própria existência (idem, p. 20). Somos porque aparecemos: esta é a aposta fenomenológica de Arendt. No entanto, tal aposta lhe apresenta um complicador. Como entender o pensamento sabendo que ele não aparece? Como defender o pensamento e ao mesmo tempo negar-lhe existência ontológica? Neste trabalho, o complicador é de outra ordem: Como se posicionar a favor de uma educação moral que tenha presente a perspectiva do pensamento, tal como o entende Arendt em sua contradição entre ser e aparecer? O pensamento, na perspectiva arendtiana, é uma atividade invisível, como já havia afirmado a tradição metafísica. No entanto, Arendt (idem, p. 125) absorve essa intuição da tradição e marca sua diferença. Para ela, o pensamento - o inteligível - não é uma recusa ou uma fuga do mundo sensível, mas uma retirada do mundo para um diálogo silencioso do eu consigo mesmo (idem, ibidem), a fim, sobretudo, de dar significado ao mundo. Nesse sentido, Sócrates é apresentado como o modelo de filósofo que soube manter-se nesse diálogo, interno e significador do mundo. Ele conseguiu unir o agir e o pensar, mantendo com cada experiência a intimidade necessária para entender que o pensar é um distanciamento do mundo e uma reaproximação sempre renovada para entendê-lo (idem, p. 55-62).

\footnotetext{
Durante toda a sua vida e até a hora da morte, Sócrates não fez mais do que se colocar no meio desta correnteza, desta ventania [do pensamento], e nela manter-se. Eis por que ele é o pensador mais puro do Ocidente. Eis por que ele não escreveu nada. Pois quem sai do pensamento e começa a escrever tem que se parecer com as pessoas que se refugiam, em um abrigo, de um vento muito forte para elas [...]. Todos os pensadores posteriores a Sócrates, apesar de sua grandeza, são como estes refugiados. (idem, p. 131)
}

É importante notar que a oposição entre o pensamento e o que aparece se mantém. O pensamento não aparece; logo, ele não é, no sentido ontológico. E, para Arendt, ser é o que aparece. Mas o pensamento em sua atividade é o que dá significado ao mundo, aquilo que aparece e é. O mundo, para Arendt, é algo puramente objetivo, mas o seu significado está fora dele mesmo e só é possível na atividade do pensamento, 
na qual nada aparece de modo objetivo ou ontológico. Assim, Hannah Arendt define o pensamento a partir de um ponto de vista liberado de interesses, de instrumentalizações, de acúmulos ou de verdades. Esse ponto de vista desinteressado - tipicamente arendtiano - significa uma nova mirada ao mundo, e não critérios morais ou normativos que surjam fora do mundo. Olhar desinteressadamente o pensamento é saber que ele não é código de conduta nem critério de conhecimento ou de manipulação para a vida prática. O pensamento, na perspectiva de Arendt, não é normativa, mas tão somente possibilidade. Hannah Arendt compreende o pensamento como reconciliação com o mundo, ao mesmo tempo que reconhece algo inegável da tradição metafísica: o estatuto do pensamento tem como característica a suspensão - retirada - do mundo. Suspensão e reconciliação do mundo - eis o ponto forte para definir o pensamento na perspectiva arendtiana (idem, p. 152) e, quem sabe, repensar a educação moral.

Seguindo a argumentação arendtiana, a atividade do pensar consistiria em um distanciar-se do mundo, mas não é trocá-lo por um mundo inteligível em busca de critérios e normas para o mundo sensível. Pensar é a possibilidade de ver o mundo, desde fora, desde uma posição privilegiada para ver a ação cotidiana, ressignificando-a (Pessoa, 1998, p. 85). A retirada do mundo é uma distração total, é como se a experiência do pensamento se originasse numa sensação de estranhamento, sobre a qual nós não temos nenhum controle (Arendt, 1995, p. 71). Retirar-se do mundo traz em si um aparente dualismo, equivocadamente reforçado pela metafísica. Mesmo porque a dupla morada humana é uma constatação da realidade: habitamos o mundo e não o habitamos quando pensamos (idem, p. 149).

Nesse sentido, o pensamento para Arendt não é passividade, mas a pura atividade humana. Não é a inação, mas o máximo da ação. $\mathrm{O}$ pensamento não é uma atividade de outro mundo, mas deste mundo. Não é fuga nem abandono, mas um distanciamento que possibilita reaproximar-se do objeto pensado com um olhar totalmente revigorado.
Quando estou pensando não me encontro onde realmente estou; estou cercada não por objetos sensíveis, mas por imagens invisíveis para os outros. É como se eu tivesse me retirado para uma terra dos invisíveis, da qual nada poderia saber, não fosse esta faculdade que tenho de lembrar e imaginar. O pensamento anula distâncias temporais e espaciais. Posso antecipar o futuro, pensá-lo como se já fosse presente, e lembrar do passado como se ele não tivesse desaparecido. (idem, p. 67)

Com Hannah Arendt, quero afirmar que o pensar não tem caráter fundador, mas apenas preparador. $\mathrm{O}$ pensamento é de possibilidade indefinida, de advento incerto e sem garantias a dar. Com isso, a autora desarma uma postura interessada e aponta para um pensar reconciliado com o mundo. Mesmo que a faculdade do pensar não gere nenhum código específico de conduta, ou seja, o pensamento não funda um marco normativo, Hannah Arendt está firme na certeza de que o pensar deva ser uma atividade atribuída a todos e não somente a alguns. O pensamento não fundamenta ontologicamente o agir moral, mas talvez seja fundamental para ele. Apesar de o pensamento lidar com o invisível e ser fora da ordem, talvez ele seja, na sua busca incessante de experiências e na destruição de critérios preestabelecidos, a possibilidade de favorecer um ambiente que desenvolva a incapacidade de fazer o mal e, assim, um ambiente propício para a educação moral.

Diante da banalidade do mal, concretizada em inúmeros casos de injustiças, violências e intolerâncias desses tempos sombrios, acredito que os/as educadores/as se encontrem diante de um grande desafio: educar para e no pensamento e, consequentemente, para e em valores. Educar na perspectiva do pensamento e ressignificar o mundo que habitamos é uma urgência. Sendo assim, o que deve ser valorizado na atividade do pensar, a fim de oferecer um ambiente propício para uma proposta de educação moral com tais características?

Educar para o pensamento é cultivar em nós e em nossas relações educativas atitudes que possibilitem o diálogo interno como uma atividade inerente à vida humana. Só o diálogo silencioso do pensamento - e 
Sócrates aqui é o modelo arendtiano por excelênciatalvez possa proteger-nos do mundo dos clichês. Nesse sentido, o pensamento enquanto diálogo interno deveria ter espaço privilegiado nos processos educativos que se queiram morais. Não obstante, é importante observar que nos processos pedagógicos geralmente o silêncio para o pensamento é raramente valorizado. Privilegia-se a fala, a leitura, o trabalho de grupo. Contudo, não quero aqui desvalorizar o diálogo com o outro (o educador, o texto, o grupo). Toda conversa dialógica - entre educador/a e educando, educando e texto e educandos entre si-deveria levar ao silêncio, isto é, deveria instigar o educando para o seu diálogo consigo mesmo. O que quero dizer é que toda aula, texto, pesquisa ou trabalho de grupo deveria colocar-se no campo de possibilidades que propiciam, naquele e naquela que se educa, uma reflexão pessoal e interna, desinteressada e capaz de dar significados ao mundo que habitamos.

Recorrendo ainda a outra imagem arendtiana, a educação em valores poderia também ser entendida como a possibilidade de se expor ao vento do pensamento (Arendt, 1995, p. 3, 12), como fazia Sócrates. Todos podemos e devemos expor-nos a esse vento para que ele possa desarrumar nossas pequenas certezas e abrir outras possibilidades, apesar dos riscos evidentes. O pensamento interrompe todas as nossas atividades, deixa-nos inseguros quando percebemos que duvidamos de coisas que antes nos davam uma segurança irrefletida. Educar em valores, na perspectiva do pensamento arendtiano, é provocar essa descontinuidade, uma ruptura com o mundo cotidiano para reconciliar-se com ele num novo significado. Abertura e imprecisão são as características próprias da atividade do pensamento que precisam ser assumidas como necessárias na prática educativa, principalmente se essa prática desejar ser moralmente significativa.

\footnotetext{
Ou, em outras palavras: pensar e estar completamente vivo são a mesma coisa, e isto implica que o pensamento tem sempre que começar de novo; é uma atividade que acompanha a vida e tem a ver com conceitos como justiça, felicidade e virtude, que nos são oferecidos pela própria linguagem, expressando
}

o significado de tudo o que aconteceu na vida e nos ocorre enquanto estamos vivos. (Arendt, 1995, p. 134)

Transmitir conhecimentos é imprescindível, mas educar para o pensamento - com abertura, imprecisão e sem garantias - parece ser uma urgência para os nossos tempos difíceis. Apesar de a atividade do pensamento lidar com o invisível e ser fora da ordem, talvez ela seja a possibilidade de favorecer um ambiente que nos proteja da banalidade do mal; talvez seja a possibilidade de construção de um ambiente desfavorável para as intolerâncias assassinas de tempos tão sombrios. Educar na perspectiva do pensamento, então, seria despertar a si mesmo e os outros do sono de irreflexão, abortando nossas opiniões vazias e irrefletidas. Educar para o pensamento seria uma atitude consciente de abrir nossas janelas conceituais para o vento do pensamento. Quiçá sejamos capazes de formar mais Sócrates do que Eichmanns, mas com uma única convicção: educar para e no pensamento é colocar-se no campo das possibilidades, e não das certezas.

\section{Referências bibliográficas}

ARENDT, Hannah. Homens em tempos sombrios. Trad. Denise Bottmann. São Paulo: Companhia das Letras, 1987. As origens do totalitarismo: antissemitismo, imperialismo, totalitarismo. Trad. Roberto Raposo. São Paulo: Companhia das Letras, 1989.

A dignidade da politica: ensaios e conferências. Trad.

Antonio Abranches. Rio de Janeiro: Relume Dumará, 1993.

A vida do espírito: o pensar, o querer, o julgar. Trad.

Antonio Abranches. Rio de Janeiro: Relume Dumará, 1995.

Eichmann em Jerusalém: um relato sobre a banalidade

do mal. Trad. José Rubens Siqueira. São Paulo: Companhia das Letras, 1999

A condição humana. 10. ed. Trad. Roberto Raposo. Rio de Janeiro: Forense Universitária, 2001.

Responsabilidade e julgamento. Trad. Rosaura Eichen-

berg. São Paulo: Companhia das Letras, 2004.

ASSY, Bethânia. Eichmann, banalidade do mal e pensamento em Hannah Arendt. In: MORAES, Eduardo J.; BIGNOTTO, Newton 
(Orgs.). Hannah Arendt: diálogos, reflexões, memórias. Belo Horizonte: Editora UFMG, 2001a. p. 136-165.

. Hannah Arendt: do mal político à ética da responsabilidade pessoal. In: AGUIAR, Odílio Alves et al. (Org.). Origens do totalitarismo: 50 anos depois. Rio de Janeiro: Relume Dumará, 2001b. p. $87-101$.

. Hannah Arendt e a dignidade da aparência. In: DUARTE, André et al. (Org.). A banalização da violência: a atualidade do pensamento de Hannah Arendt. Rio de Janeiro: Relume Dumará, 2004. p. 161-171.

BERNSTEIN, Richard. ¿Cambió Hannah Arendt de opinión?: del mal radical a la banalidad del mal. In: BIRULÉS, Fina. Hannah Arendt: el orgullo de pensar. Trad. Xavier Calvo. Barcelona: Gedisa, 2002. p. 235-257.

El mal radical: una indagación filosófica. Trad. Marcelo Burello. Buenos Aires: Lilmod, 2004.

CORREIA, Adriano. Crime e responsabilidade: a reflexão de Hannah Arendt sobre o direito e a dominação totalitária. In: DUARTE, André et al. (Org.). A banalização da violência: a atualidade do pensamento de Hannah Arendt. Rio de Janeiro: Relume Dumará, 2004. p. 83-98.

DUARTE, André. O pensamento à sombra da ruptura: política e filosofia em Hannah Arendt. São Paulo: Paz e Terra, 2000.

ETTINGER, Elzbieta. Hannah Arendt e Martin Heidegger. Trad. Mario Pontes. Rio de Janeiro: Jorge Zahar, 1996.

KOHN, Jerome. O mal e a pluralidade: o caminho de Hannah Arendt em direção à Vida do espírito. In: AGUIAR, Odílio Alves et al. (Org.). Origens do totalitarismo: 50 anos depois. Rio de Janeiro: Relume Dumará, 2001. p. 9-36.

KRISTEVA, Julia. O gênio feminino: a vida, a loucura, as palavras. Trad. Eduardo Francisco Alves. Rio de Janeiro: Rocco, 2002. tomo I: Hannah Arendt.

LAFER, Celso. Hannah Arendt: pensamento, persuasão e poder. 2. ed. Rio de Janeiro: Paz e Terra, 2003.
LECHTE, John. Cinquenta pensadores contemporâneos essenciais: do estruturalismo à pós-modernidade. Trad. Fábio Fernandes. Rio de Janeiro: DIFEL, 2002.

PESSOA, Gláucia. O que significa pensar: Hannah Arendt e a vida do espírito. Dissertação (Mestrado em Filosofia) - Departamento de Filosofia, Pontifícia Universidade Católica do Rio de Janeiro, Rio de Janeiro, 1998.

SOUKI, Nádia. Hannah Arendt e a banalidade do mal. Belo Horizonte: Editora UFMG, 1998.

WATSON, David. Hannah Arendt. Trad. Luiz Antonio Aguiar e Marisa Sobral. Rio de Janeiro: DIFEL, 2001.

YOUNG-BRUEHL, Elizabeth. Por amor ao mundo: a vida e a obra de Hannah Arendt. Trad. Antônio Trânsito. Rio de Janeiro: Relume Dumará, 1997.

MARCELO ANDRADE, doutor em ciências humanas pela Pontifícia Universidade Católica do Rio de Janeiro (PUC-Rio), é professor do Programa de Pós-Graduação em Educação na mesma instituição, no qual coordena, em parceria com Vera Maria Candau, o grupo de estudos sobre Cotidiano, Educação e Culturas. Publicações recentes: Tolerância e educação: pensar nas fronteiras da filosofia e da pedagogia (Revista de Filosofia Unisinos, v. 8, n. 03 , p. 276-286, set./dez. 2007); Tolerar é pouco? Pluralismo, mínimos éticos e prática pedagógica (Petrópolis: Depetrus/Novamerica, 2009); A diferença que desafia a escola: a prática pedagógica e a perspectiva intercultural (Rio de Janeiro: Quartet/FAPERJ, 2009). Pesquisa atual: "Diversidade cultural, prática pedagógica e mínimos éticos: articulações entre a ética aplicada e os processos de ensino-aprendizagem", financiada pelo CNPq e pela FAPERJ. E-mail:marcelo.andrade@pesquisador.cnpq.br

Recebido em fevereiro de 2009 Aprovado em novembro de 2009 
Marcelo Andrade

\section{A banalidade do mal e as possibilidades da educação moral: contribuições arendtianas}

Mais do que uma época de crises, enfrentamos hoje uma crise de época, na qual a educação tem papel fundamental a desempenhar. Nesse sentido, o trabalho revisita a obra de Hannah Arendt, filósofa que pensou e viveu em tempos sombrios, a fim de entender alguns conceitos fundamentais para repensar hoje a educação moral ou a educação em valores. Com pesquisa centrada nas obras Eichmann em Jerusalém: um relato sobre a banalidade do mal e A vida do espírito, o trabalho visa compreender como e por que Hannah Arendt cunhou o conceito de banalidade do mal e em que sentido ele se relaciona com o vazio do pensamento e com uma proposta de educação em valores.

Palavras-chave: Hannah Arendt; banalidade do mal; vazio do pensamento; educação moral; educação em valores.
The banality of evil and the possibilities of moral education: Hannah Arendt's contribution

We face today the crisis of an era rather than an era of crisis, in which education has a fundamental role to perform. In this sense, this paper revisits the work of Hannah Arendt, a philosopher who thought and lived in dark times, in order to understand better some fundamental concepts necessary for rethinking moral education or education in values. Based on analysis of two of Hannah Arendt's studies, entitled Eichmann in Jerusalem: a report on the banality of evil and The life of the mind, this paper seeks to comprehend how and why Hannah Arendt coined the concept of banality of evil. This paper also seeks to understand in what sense this concept relates to both the emptiness of thought and to a proposal for education in values.

Key words: Hannah Arendt; banality of evil; emptiness of thought; moral education; education in values.

\section{La banalidad del mal y las} posibilidades de la educación moral: contribuciones arendtianas

Más que una época de crisis, enfrentamos hoy una crisis de época en la cual la educación desempeña un papel fundamental. En este sentido, el presente trabajo es una relectura de la obra de Hannah Arendt, filósofa que pensó y vivió en tiempos sombríos, con el fin de aclarar algunos conceptos que son fundamentales para que hoy pueda repensarse la educación moral o la educación en valores. A través de un estudio centrado en las obras Eichmann en Jerusalén: un estudio sobre la banalidad del mal y La vida del espiritu, este trabajo busca comprender cómo y por qué Hannah Arendt acuñó el concepto banalidad del mal y en qué sentido este se relaciona con el vacio del pensamiento y con una propuesta de educación en valores.
Palabras claves: Hannah Arendt; banalidad del mal; vacio del pensamiento; educación moral; educación en valores. 